\title{
Nutritional imbalance in smallholder oil palm plantations in Indonesia
}

\author{
Lotte S. Woittiez $\mathbb{D} \cdot$ Maja Slingerland $\mathbb{D} \cdot$ Rukaiyah Rafik $\cdot$ Ken E. Giller $\mathbb{D}$
}

Received: 2 October 2017 / Accepted: 12 March 2018/Published online: 21 March 2018

(C) The Author(s) 2018

\begin{abstract}
In Indonesia more than $40 \%$ of the area under oil palm is owned by smallholders. The productivity in smallholder plantations is usually less than in large plantations, and limited fertiliser applications may be one of the key reasons. We investigated the use of fertilisers by $>300$ smallholder farmers in Sumatra and Kalimantan, some of whom were involved in training programmes aimed at yield improvement. In our sample, the total applications of $\mathrm{N}$ were largest $\left(166 \mathrm{~kg} \mathrm{ha}^{-1}\right.$ year $\left.^{-1}\right)$, followed by $\mathrm{K}$ $(122 \mathrm{~kg})$ and $\mathrm{P}(56 \mathrm{~kg})$. The applications of $\mathrm{K}$ were insufficient to compensate for the off-take with a production of 20 tonne fruit bunches $\mathrm{ha}^{-1}$ year $^{-1}$, while $\mathrm{N}$ applications were excessive. On average, farmers applied $1130 \mathrm{~kg}$ fertiliser $\mathrm{ha}^{-1}$ year $^{-1}$, and relied strongly on subsidised fertilisers, especially NPK Ponska (66\%) and urea (39\%). The average costs
\end{abstract}

L. S. Woittiez $(\bowtie) \cdot$ M. Slingerland · K. E. Giller

Wageningen University, Droevendaalsesteeg 1,

6708 PB Wageningen, The Netherlands

e-mail: lotte.woittiez@wur.nl

M. Slingerland

e-mail: maja.slingerland@wur.nl

K. E. Giller

e-mail: ken.giller@wur.nl

R. Rafik

Setara Jambi, Jalan Kebun Daging, Mayang Mangurai,

Kota Baru, Jambi 36129, Indonesia

e-mail: uki@setarajambi.org for fertiliser application were USD $225 \mathrm{ha}^{-1}$ year $^{-1}$. Trained farmers applied significantly more $\mathrm{P}$ in one research area, but for the other nutrients and research areas, there was no significant difference between trained and untrained farmers. Plantation size and nutrient application were weakly correlated in some areas, but not in the sample as a whole. Previously reported nutrient application rates were mostly less than our findings indicated, suggesting that actual nutrient limitations may be more severe. To overcome nutrient limitations and enhance nutrient use efficiency, we recommend that fertilisers are used in the correct balance; a ground cover vegetation is maintained to protect against erosion; and the application of empty fruit bunches is encouraged.

Keywords Fertiliser - Nutrient management . Training · Good agricultural practices $\cdot$ Yield $\cdot$ Soil fertility

\section{Introduction}

Oil palm (Elaeis guineensis Jacq.) is a highly efficient producer of vegetable oil, with an estimated potential production of well over 10 tonne oil ha ${ }^{-1}$ year $^{-1}$ (Corley 2009a). Indonesia is the world's largest palm oil producer, with a cultivated area of 11.8 million hectares in 2017 (USDA 2017) equivalent to about 
$11 \%$ of the combined land area of Sumatra and Kalimantan. Oil palm expansion in Indonesia and Malaysia has been associated with tropical deforestation (Abood et al. 2015; Gaveau et al. 2016), and expansion of plantations into peat forests has caused large emissions of $\mathrm{CO}_{2}$ (Murdiyarso et al. 2010). If oil palm is to continue its role as the main global source of vegetable oil, then rapid and uncontrolled expansion need to be replaced with intensification and controlled expansion into degraded areas (Corley 2009a; Smit et al. 2013; Afriyanti et al. 2016).

In terms of poverty reduction in rural Indonesia, oil palm has played an important and mostly positive role (Gatto et al. 2015). Currently over $40 \%$ of the Indonesian oil palm area is managed by smallholder farmers (Molenaar et al. 2013), many of whom depend on oil palm as their primary source of income (Euler et al. 2017). Indonesian smallholder farmers are usually classified as plasma farmers (also called scheme or tied; i.e. fields were planted as a company scheme and bunches are sold to the company mill); independent farmers (i.e. fields were planted independently by smallholder farmers, and bunches can usually be sold to any mill); and mixed farmers (or tied + , i.e. farmers who own both plasma and independent fields; Vermeulen and Goad 2006). Most smallholder farmers manage their plantations individually, and yields are generally around 3-4 tonne oil $\mathrm{ha}^{-1}$ year $^{-1}$, which is less than in large plantations (Molenaar et al. 2013). The underlying agronomic factors causing this yield gap have been investigated in multiple studies and include poor planting material (Papenfus 2002), delayed replanting (Koczberski and Curry 2003), infrequent harvesting (Lee et al. 2013; Euler et al. 2016), limited fertiliser use (Papenfus 2002; Koczberski and Curry 2003; Euler et al. 2016), or a combination of the above (Molenaar et al. 2010, 2013). If smallholder yields are to be improved, then the implementation of good agricultural practices (GAP) is required. The Roundtable on Sustainable Palm Oil (RSPO) considers GAP, including good management of soil fertility, to be one of the key pillars of sustainability (RSPO 2013). To date, the number of RSPO-certified smallholder farmers in Indonesia remains very small, but there is a strong drive to increase this (RSPO 2017). The Indonesian Sustainable Palm Oil (ISPO) certification, which was introduced in 2011 and which has been mandatory since 2014 (Rival et al. 2016) is reinforcing the attention for GAP. The implementation of GAP is particularly important in smallholder plantations to create added value (in the form of yield increase) to pay for the expensive certification process (Rietberg and Slingerland 2016) and to facilitate the inclusion of smallholder farmers in the certified supply chain.

Good fertiliser management is a key aspect of GAP; the excessive use of fertilisers is financially unattractive and damaging for the environment (Van Noordwijk and Cadisch 2002), while insufficient fertiliser use leads to yield limitations and nutrient mining. In mature oil palm plantations the application of $\mathrm{N}, \mathrm{P}, \mathrm{K}$, and $\mathrm{Mg}$ as fertiliser is usually required, as most soils cannot supply sufficient nutrients to meet palm demand (Goh 2005). Ng et al. (1999) propose that on tropical soils of poor fertility, the total demand of a mature plantation producing 20 tonne fresh fruit bunches (FFB) per year is $129.5 \mathrm{~kg} \mathrm{~N}, 16.4 \mathrm{~kg} \mathrm{P}$, $236 \mathrm{~kg} \mathrm{~K}$, and $38 \mathrm{~kg} \mathrm{Mg}$ per hectare. Some of these nutrients are supplied in the rainfall, so the total input requirement to sustain the yield of $20 \mathrm{t} F F B$ is $112.5 \mathrm{~kg} \mathrm{~N}, 14.0 \mathrm{~kg} \mathrm{P}, 204.4 \mathrm{~kg} \mathrm{~K}$ and $33.2 \mathrm{~kg} \mathrm{Mg}$ per hectare per year ( $\mathrm{Ng}$ et al. 1999). From these inputs, 10-20\% are lost through leaching and run-off ( $\mathrm{Ng}$ et al. 1999), especially during periods of high rainfall (Banabas et al. 2008; Comte et al. 2015) and after large nutrient applications (Comte et al. 2015). From the nutrients taken up by the oil palm, 30-50\% are allocated to the palm trunk ( $\mathrm{Ng}$ et al. 1999; Corley 2009b). These nutrients are mostly no longer available to the palm for other purposes and are considered as being removed from the balance, although palms are able to re-mobilise some nutrients from the trunk when concentrations in the reserve tissue are sufficiently high (Foster and Prabowo 2006). Nutrients allocated to the oil palm leaves and male inflorescences are recycled within the plantation after pruning and harvesting, and do not affect the nutrient balance. Nutrients allocated to the bunches are removed from the plantation at harvesting (Corley 2009b; Donough et al. 2016) and are considered as being removed from the balance. The share of total nutrients in the balance that are removed in 20 tonne of bunches are 51, 64, 37, and $58 \%$ for $\mathrm{N}, \mathrm{P}, \mathrm{K}$ and $\mathrm{Mg}$, respectively. The nutrient content of crude palm oil (CPO) is negligible: $44 \mathrm{~g} \mathrm{~N}, 18 \mathrm{~g} \mathrm{P},<10 \mathrm{~g} \mathrm{~K}$, and $3 \mathrm{~g} \mathrm{Mg}$ per tonne CPO (Donough et al. 2016). This means that most of the nutrients remain behind in the empty bunches and in the mill waste streams, which can be recycled in the 
plantation to meet part of the palm nutrient demand (Ng et al. 1999; Chiew and Rahman 2002; Comte et al. 2013). To maximise yields, nutrients must be applied in the correct balance (Janssen et al. 1990; Goh et al. 2009). Some guidelines for fertiliser applications in mature plantations on different soil types have been proposed (Goh 2005), based on randomised fertiliser trials combined with regular tissue sampling (Webb 2009).

It is clear from previous studies that fertiliser applications by smallholder farmers in Indonesia are not optimal for producing good yields, but we lack an in-depth analysis of nutrient use by smallholders. In addition, the drivers and constraints underlying farmers' choices of fertilisers are poorly understood, but strongly affect the success of training interventions on fertiliser use. We investigated the use of fertilisers in smallholder oil palm plantations in Indonesia by reviewing the literature and conducting a survey with $>300$ farmers in three provinces in Indonesia. We also assessed the effect of different training interventions on farmers' fertiliser use. Based on the findings from the review and the survey, we discuss the opportunities for improving nutrient management in smallholder plantations, and we formulate targeted recommendations to improve fertiliser management and increase plantation profitability and sustainability.

\section{Methods}

Between March and August 2016 we conducted surveys with 309 smallholder farmers in three provinces in Sumatra (Riau and Jambi) and Kaliman$\tan$ (West Kalimantan). In each of the selected areas, local or international non-governmental organisation (NGOs) were actively providing training on GAP to some of the farmers. Important elements of GAP that were trained in all areas were harvesting (regular and at correct ripeness); weeding (circle and path weeding; selective weeding); pruning (removal and retention of the correct number of leaves) and balanced fertiliser application that meets the palm nutrient demand.

\section{Research areas}

Kumpeh (Jambi province; Kumpeh district; Ramin village) is a transmigration and former plasma area that was mostly planted in 2002 and was abandoned by the company around 2008, after which the farmers became independent. There was an active cooperative in the first years that no longer functions. Farmers in Ramin had good access to several mills to sell their FFB. They mostly sold through traders, who were also from the village. In Ramin, six farmers were trained for 3 years (starting in 2014) and they were hosting an experimental demonstration plot [organised by Wageningen University and Netherlands Development Organisation (SNV)] at the time of the research. In the demonstration plots, good management practices were implemented. The sample composition is shown in Table 1. For the trained farmers, the survey investigated the practices in the fields outside the demonstration plot.

Tanjung Jabung Barat (Jambi province; Tanjung Jabung Barat (TJB) district; Sungai Rotan village) is an area of local independent oil palm farmers. All farmers sell their bunches through traders. A farmer group with 86 voluntary members was initiated by Yayasan Setara Jambi in 2013, to prepare for RSPO certification. Five selected farmer group members received a 1-day GAP training by agronomists from the plantation company Asian Agri, in a classroom setting. The trained farmers then provided training to the other farmers in the group, and one Asian Agri agronomist remained available to answer the farmers' questions. Setara Jambi provided additional training on making a farmer group and RSPO certification. The sample composition is shown in Table 1. All trained farmers were members of the farmer group, and all selected farmers were in the direct network of six intensively trained local leaders.

Siak (Riau province; Siak district; Dosan, Teluk Mesjid, Benayah, and Sungai Limau villages) is a semi-independent smallholder area established mostly on peat soils. All villages, apart from Dosan, had functional cooperatives at the time of the survey. Bunches were sold through these cooperatives. In 2009, a three-day training was provided by a British oil palm specialist together with Wageningen University, World Wide Fund for Nature (WWF) and the Indonesian environmental NGO Elang. During the training, mornings were spent in the classroom, while afternoons were used to establish a good practices demonstration plot. Most active participation was from Dosan farmers, and there was also some attendance from Teluk Mesjid. Standard Operating 
Table 1 Number of trained and untrained farmers included at each of the research areas

\begin{tabular}{lccc}
\hline Region & \# trained farmers & \# untrained farmers & Total sample size \\
\hline Kumpeh & 6 & 56 & 62 \\
Tanjung Jagung Barat (TJB) & 53 & 12 & 65 \\
Siak & 11 & 39 & 50 \\
Sintang & 6 & 60 & 66 \\
Sekadau & 6 & 60 & 66 \\
Total & 82 & 227 & 309 \\
\hline
\end{tabular}

Procedures were drafted in Dosan village after the training. The sample farmers were selected through key informant suggestions, from four different villages (to achieve spatial separation). Nine trained farmers from Dosan and two trained farmers from Teluk Mesjid were selected; the remaining 39 farmers were untrained (Table 1).

Sintang (West-Kalimantan province; Sintang regency; Sungai Tebelian disctrict; Mrarai village) is an area with farmers from mixed transmigration and local (Dayak) origin. Farmers mostly own both plasma and independent fields. Plasma farmers sell their bunches through a cooperative; independent farmers sometimes use traders or mix their independent bunches with plasma loads. All bunches are sold to a company mill that processes only smallholder bunches. The mill is regularly overloaded. Trained farmers were all members of an independent farmers' cooperative, which traded directly with the mill. The independent farmer cooperative was initiated and supported by WWF since 2012. Six farmers with both plasma and independent fields were trained for three years (starting in 2014) and they were hosting an experimental demonstration plot (organised by Wageningen University and SNV) at the time of the research. In the demonstration plots, good management practices were implemented. The sample composition is shown in Table 1. For the trained farmers, the survey discussed the practices in the fields outside the demonstration plot.

Sekadau (West-Kalimantan province; Sekadau Hilir district; Gonis Rabu, Gonis Tekam, Empring, and Segori villages) is a mixed area with plasma and independent fields. Most farmers sell their bunches through the plasma cooperatives. A training project was set up by an international and a local NGO (World Education and Credit Union Keling Kumang), supported by Solidaridad and Stichting Doen. In the project, a Training of Trainers approach was implemented through Farmer Field Schools, with a first round of classes in 2012 and 2013. The GAP trainings were either for mature or for immature plantations. Each course consisted of 13 classes divided over 13 weeks. Trainers were NGO staff who were previously trained by plantation agronomists, as preparation for the project. In addition to GAP trainings, financial literacy trainings were also provided. For the sample, six farmers trained in the first round of Farmer Field Schools, and 60 untrained farmers in the direct network of the trained farmers were selected (Table 1).

\section{Surveys}

The surveys served multiple purposes: to assess the current management practices of smallholder farmers; to assess the impact of trainings on farmer practices; and to assess the spread of knowledge through informal networks. To facilitate the second and third objectives, the farmers participating in the survey were selected non-randomly. In all areas apart from Siak, a group of six farmers who had participated in the trainings were selected through the training providers, and interviewed. Each of these farmers was asked to name 10 farmers in their network, and these farmers were also interviewed, following the snowball sampling procedure (Goodman 1961). In Siak, farmers were non-randomly selected from four different villages through local enquiries, without a fixed sampling structure but aiming at maximum geographic spread (i.e. avoiding neighbours and close relatives). We asked selected farmers about their plantation management, particularly harvesting, weeding, and fertiliser application. We also asked whether they had recently changed their practices, and if so, why. Finally we asked open questions about the information flows, focusing on which farming-related topics were regularly discussed (e.g. yield), with 
whom these topics were discussed (e.g. family members), and the reasons for discussion (e.g. to compare own situation with others). After the surveys the answers were grouped and coded to facilitate further analysis.

\section{Literature review}

Because our sample was influenced by training, we compared our results with data from the literature. We searched grey (Google Scholar) and peer-reviewed (Web of Science) literature for reports on (nutrient) management practices in oil palm smallholder plantations in Indonesia, and we selected publications which reported fertiliser application rates per hectare. The selected publications are described in Table 2. Soliman et al. (2016) and Lee et al. (2013) considered only $\mathrm{N}$; the other studies took at least $\mathrm{N}, \mathrm{P}$ and $\mathrm{K}$ into account.

\section{Statistical analysis}

Outliers in nutrient applications were identified as points that were beyond the three times interquartile range (indicated with an asterisk in the box plots) and were removed before analysis. Plantation area and nutrient use data were not normally distributed, and were analysed using non-parametric tests. Overall differences between areas in terms of nutrient application and costs were analysed using the KruskalWallis test of independent medians, with pairwise comparison and Bonferroni correction. The differences between specific areas and the effect of training on nutrient use were analysed using the MannWhitney $U$ test to compare group medians. Correlation between plantation area and nutrient application was calculated using the Spearman rank correlation test. Differences were considered significant when $p<0.05$. Analyses were conducted using SPSS.

\section{Results}

Nutrient application surveys

Nutrient application rates in each research area are shown in Fig. 1. Most farmers applied substantial amounts of fertiliser. In all areas but Siak, the average applications for each research area were greater than $300 \mathrm{~kg}$ of nutrient per hectare, which was equivalent to at least $1000 \mathrm{~kg}$ of fertiliser per hectare. Across all research areas, the average applications of $\mathrm{N}$ were largest $\left(166 \mathrm{~kg} \mathrm{ha}^{-1} \mathrm{year}^{-1}\right)$, followed by $\mathrm{K}(122 \mathrm{~kg})$ and $\mathrm{P}(56 \mathrm{~kg})$. Compared with the required input rates (112.5 kg N, $14.0 \mathrm{~kg} \mathrm{P}$, and $204.4 \mathrm{~kg} \mathrm{~K}$ per hectare, to sustain a yield of 20 tonne FFB; $\mathrm{Ng}$ et al. 1999), the average applications of $\mathrm{N}$ and $\mathrm{P}$ were more than required in all areas apart from Siak, but K applications were only $45-70 \%$ of the required input rates. There were large variations in the quantities of nutrients applied among farmers. The research areas were significantly different in terms of median $\mathrm{N}$

Table 2 Overview of the case studies included in the literature review

\begin{tabular}{|c|c|c|c|}
\hline Source & Location & Sample size & Description \\
\hline Comte et al. (2015) & Riau & $\sim 2000 \mathrm{ha}$ & Plasma (3 groups) \\
\hline Euler et al. (2016) & Jambi & 173 households & Plasma and independent \\
\hline \multirow[t]{4}{*}{ Harsono et al. (2012) } & Central Kalimantan & $\sim 10,000$ ha & Plasma \\
\hline & West Kalimantan & $\sim 12,000$ ha & Independent \\
\hline & Riau & $\sim 7500$ ha & Plasma \\
\hline & North Sumatra & $\sim 6500$ ha & Independent \\
\hline \multirow[t]{2}{*}{ Lee et al. (2013) (Ch 4) } & Sumatra & 44 households & Plasma \\
\hline & Sumatra & 27 households & Independent \\
\hline \multirow[t]{2}{*}{ Lifianthi and Husin (2012) } & South-Sumatra, dryland & 30 households & Plasma \\
\hline & South-Sumatra, peatland & 30 households & Plasma \\
\hline Soliman et al. (2016) & Sumatra & 170 households & Plasma and independent \\
\hline
\end{tabular}



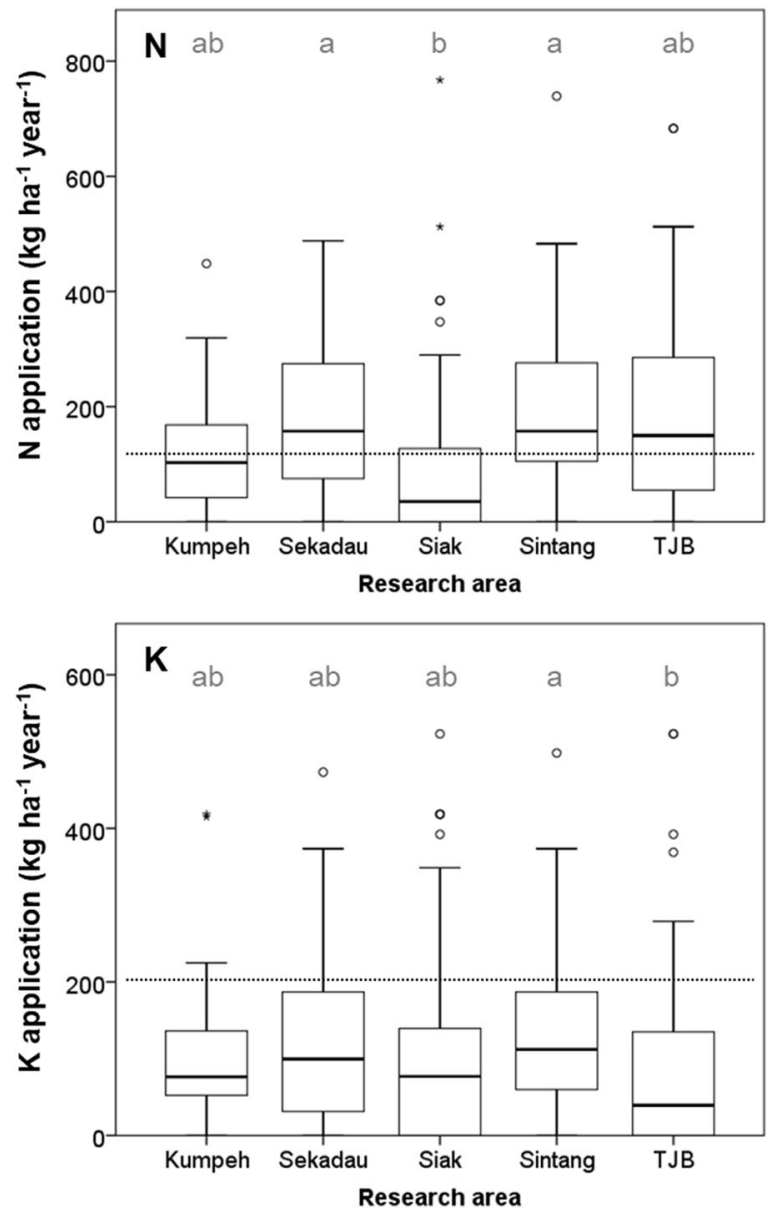

Fig. 1 Application rates of elemental N, P and K in the five research areas. Significant differences between research areas $(p<0.05)$ are indicated with letters. Whiskers show the minimum and maximum values; the box shows the 1st and 3rd quartile; the line shows the median. Values of $>1.5$ interquartile range (IQR; not considered outliers in the analysis) are

$(p<0.001), \mathrm{P}(p<0.001)$ and $\mathrm{K}$ application rates ( $p<0.05$; Fig. 1). Overall 15\% of the farmers applied no $\mathrm{N} ; 20 \%$ applied no $\mathrm{P}$; and $18 \%$ applied no $\mathrm{K}$ fertilisers. Excessive nutrient applications (defined here as more than 1.5 times the offtake rates for $\mathrm{N}$ and $\mathrm{K}$ ) were observed in $25 \%$ of the cases for $\mathrm{N}, 72 \%$ of the cases for $\mathrm{P}$, and $5 \%$ of the cases for $\mathrm{K}$, excluding outliers.

Nutrient application rates reported in the literature

The largest $\mathrm{N}$ applications (around $240 \mathrm{~kg} \mathrm{ha}^{-1}$ year $^{-1}$; Fig. 2) were reported by Lifianthi and Husin (2012) in South-Sumatra, and were about twice as

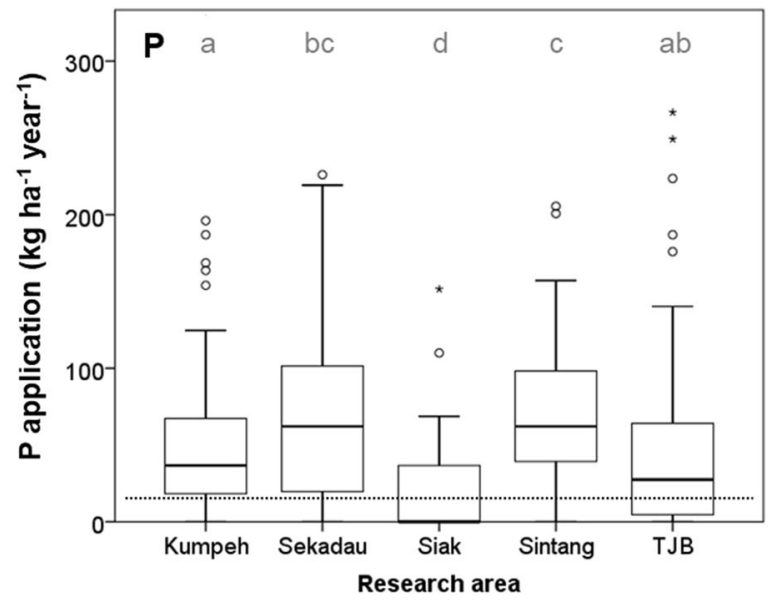

shown as circles, and > 3.0 IQR (considered as true outliers) are shown as asterisks. The dashed line shows the approximate nutrient removal rate at 20 tonne FFB per ha per year $(\mathrm{Ng}$ et al. 1999). Outliers with values $>800 \mathrm{~kg} \mathrm{~N} \mathrm{ha}{ }^{-1} ;>300 \mathrm{~kg} \mathrm{P}$ $\mathrm{ha}^{-1}$, and $>700 \mathrm{~kg} \mathrm{~K} \mathrm{ha}^{-1}$ were excluded from the graphs

much as the nutrient offtake. Harsono et al. (2012) reported $\mathrm{N}$ applications which were more than six times less, and which were around $60 \%$ of the calculated offtake. Similar N applications were reported by Comte et al. (2015). A somewhat smaller range was observed in the application of $\mathrm{P}$, but maximum applications $\left(114 \mathrm{~kg} \mathrm{ha}^{-1}\right.$; Harsono et al. 2012) were over 10 times more than the calculated offtake. For $\mathrm{K}$, the maximum application rate (144 $\mathrm{kg} \mathrm{ha}^{-1}$; Lifianthi and Husin 2012) was well below the calculated offtake rate, and the smallest applications (21 kg ha ${ }^{-1}$; Comte et al. 2015) were almost ten times less (Fig. 2). 


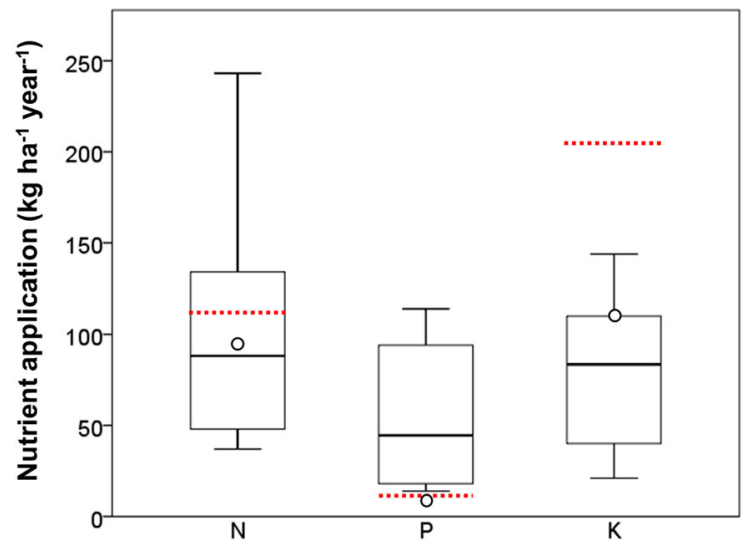

Fig. 2 Nutrient applications (elemental N, P and K) in smallholder oil palm plantations from eleven case studies presented in six published papers that were found through the literature review (see Table 2). Whiskers show the minimum and maximum values; the box shows the 1 st and 3rd quartile; the line shows the median. The dashed lines shows the nutrient removal at a production of 20 tonnes fruit bunches $\mathrm{ha}^{-1}$ year $^{-1}$ ( $\mathrm{Ng}$ et al. 1999), and the circles show the average nutrient application in large plantations in Indonesia in 2010 (Heffer 2013)

Types of fertilisers used, and costs

On average, farmers applied $1130 \mathrm{~kg}$ fertilisers ha ${ }^{-1}$ year $^{-1}$, of which almost half was the subsidised fertiliser NPK Ponska (Table 3). NPK Ponska was applied by $66 \%$ of the farmers, and contains $15 \% \mathrm{~N}$,
$15 \% \mathrm{P}_{2} \mathrm{O}_{5}$ (equivalent to $6.5 \% \mathrm{P}$ ) and $15 \% \quad \mathrm{~K}_{2} \mathrm{O}$ (equivalent to $12.5 \% \mathrm{~K}$ ). NPK Pelangi has the same composition and was applied by $9 \%$ of the farmers. The NPK fertilisers were supplemented with urea $(46 \% \mathrm{~N})$, dolomite $\left(\mathrm{CaMg}\left(\mathrm{CO}_{3}\right)_{2}\right.$; around $\left.15 \% \mathrm{Mg}\right)$, $\mathrm{KCl}(50 \% \mathrm{~K})$ and SP-36 $(16 \% \mathrm{P})$. Less than $1 \%$ of the farmers used organic fertilisers such as manure or empty fruit bunches $(0.32 \% \mathrm{~N}, 0.04 \% \mathrm{P}, 0.96 \% \mathrm{~K}$, $0.07 \% \mathrm{Mg}$ per fresh weight; water content $60-65 \%$; Gurmit Singh et al. 1990).

In total, farmers spent around 225 USD per hectare per year on fertilisers, mostly on NPK Ponska, $\mathrm{KCl}$, urea, and SP-36 (Fig. 3 and Table 3). There were no significant differences among the research areas in terms of fertiliser expenditure $(p>0.05)$. NPK Ponska, urea, SP-36, NPK Pelangi, and ZA are subsidised. It appears that the fertiliser subsidies strongly influenced farmers' choices (Table 3). Because $\mathrm{KCl}$ is not subsidised, the average costs of its use were larger than for urea and dolomite, although the average application was less. Dolomite is not subsidised, but is very cheap and was used by farmers as the main source of magnesium. In addition, it appeared from the interviews that farmers also use dolomite to "improve the soil" and to reduce soil acidity (data not shown).

Table 3 Nine most common fertilisers used by smallholder farmers $(n=309)$ in the research areas

\begin{tabular}{|c|c|c|c|c|c|c|c|c|c|}
\hline \multirow[t]{2}{*}{ Fertiliser brand } & \multirow[t]{2}{*}{ Composition } & \multirow[t]{2}{*}{ Price (USD tonne ${ }^{-1}$ ) } & \multirow[t]{2}{*}{$n$} & \multirow[t]{2}{*}{ Use $(\%)$} & \multicolumn{3}{|c|}{ Application $\left(\mathrm{kg} \mathrm{ha}^{-1}\right.$ year $\left.^{-1}\right)$} & \multicolumn{2}{|c|}{ Costs (USD ha ${ }^{-1}$ year $^{-1}$ ) } \\
\hline & & & & & Rate & Mean & SD & Mean & SD \\
\hline NPK Ponska & $15-15-15-0$ & 192 & 294 & 66 & 692 & 457 & 550 & 88 & 105 \\
\hline Urea & $46-0-0-0$ & 150 & 299 & 39 & 456 & 178 & 314 & 27 & 47 \\
\hline Dolomite & $0-0-0-20$ & 33 & 287 & 25 & 535 & 123 & 432 & 4 & 14 \\
\hline $\mathrm{KCl}$ & $0-0-60-0$ & 325 & 299 & 21 & 510 & 107 & 325 & 35 & 106 \\
\hline SP-36 & $0-36-0-0$ & 167 & 301 & 21 & 452 & 95 & 241 & 16 & 40 \\
\hline NPK Pelangi & $15-15-15-0$ & 192 & 303 & 9 & 756 & 68 & 243 & 13 & 47 \\
\hline TSP & 0-46-0-0 & 304 & 300 & 7 & 400 & 28 & 125 & 9 & 38 \\
\hline ZA & $21-0-0-0$ & 117 & 302 & 4 & 450 & 18 & 119 & 2 & 14 \\
\hline $\mathrm{RP}$ & $0-20-0-0$ & 88 & 302 & 1 & 1000 & 10 & 137 & 1 & 12 \\
\hline
\end{tabular}

SP-36 = single super phosphate; TSP = triple super phosphate; $\mathrm{ZA}=$ sulphate of ammonium; RP = rock phosphate

The column "Composition" refers to the ratio $\mathrm{N}: \mathrm{P}_{2} \mathrm{O}_{5}: \mathrm{K}_{2} \mathrm{O}: \mathrm{MgO}$. The column $n$ shows the number of valid responses. The column "Use (\%)" indicates the percentage of farmers who apply that fertiliser. The application rate shows the application among users only, while the mean application and its standard deviation were calculated over the entire sample of users and non-users. The costs were also calculated over the entire sample. Fertiliser composition and prices were obtained through discussions with farmers and fertiliser dealers 


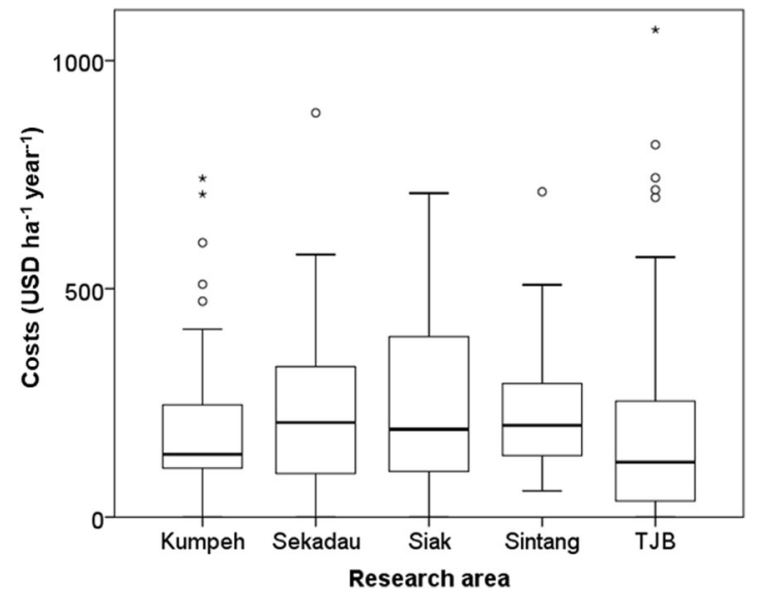

Fig. 3 Costs of fertiliser applied by smallholder farmers in the research areas. Whiskers show the minimum and maximum values; the box shows the 1st and 3rd quartile; the line shows the median. Values of $>1.5$ inter-quartile range (IQR; not considered outliers in the analysis) are shown as circles, and > 3.0 IQR (considered as true outliers) are shown as asterisks. Outliers with values $>$ USD 1050 were excluded from the graph

Effect of training and farm size

In all areas, more trained than untrained farmers indicated that they changed the types of fertilisers that they applied in recent years; $40-100 \%$ of trained farmers and $30-75 \%$ of untrained farmers said they changed their practices. For the quantities of $\mathrm{N}$ and $\mathrm{K}$ applied, there was no significant difference between trained and untrained farmers in any of the research areas, nor for the sample as a whole (Fig. 4). For P, the application rates of trained farmers in Siak was significantly greater than those of untrained farmers $(p<0.05)$, but there was no significant difference over the entire sample.

Farmers with larger plantation areas were significantly more likely to receive trainings than farmers with smaller areas $(p<0.001$ for the whole sample; $p<0.05$ in Jambi and Sintang; not significant for the other areas; data not shown). $\mathrm{N}$ application rate was significantly positively correlated with plantation size in Sintang ( $r h o=0.285 ; p<0.05)$, and $\mathrm{P}$ and $\mathrm{K}$ application rates were significantly positively correlated with plantation size in TJB (P: rho $=0.309$; $p<0.05$; $\mathrm{K}$ : rho $=0.282 ; p<0.05)$. In the other areas, and over the sample as a whole, the application rates of $\mathrm{N}, \mathrm{P}$ and $\mathrm{K}$ were not significantly correlated with plantation size (Fig. 5).

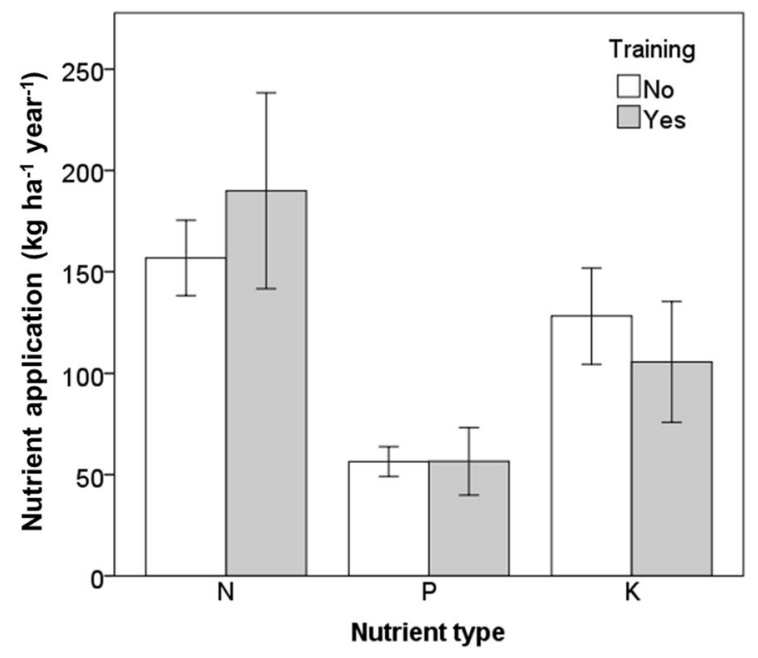

Fig. 4 Nutrient application in relation to training for elemental N, P and K. Outliers with application rates of $>1000 \mathrm{~kg} \mathrm{ha}^{-1}$ year $^{-1}$ (two for $\mathrm{N}$ and two for $\mathrm{K}$ ) were excluded from the graph. There were no significant differences in nutrient application between trained and untrained groups in any of the research sites

Networks and information sharing

The sampling of the farmers focused specifically on the spread of information through farmer networks. The farmers were asked with whom they shared information about farming, and what they discussed. Farmers mostly shared information with family members and friends (Fig. 6a) and the most important topic they discussed was fertiliser application (Fig. 6b). Less than $15 \%$ of farmers indicated that they did not discuss their farming practices with anyone.

When asked why they applied limited amounts of fertiliser, farmers mostly cited fertiliser and cash availability as the key constraints. The availability of subsidised fertilisers for farmers who were not part of a cooperative or farmer group was particularly problematic. The farmers indicated that cooperatives and traders sometimes provided loans for fertilisers. None of the interviewed farmers indicated that they borrowed money from a bank for the purpose of buying fertilisers.

\section{Discussion}

The results from the survey and the literature provide important insights into the practices of the farmers in 

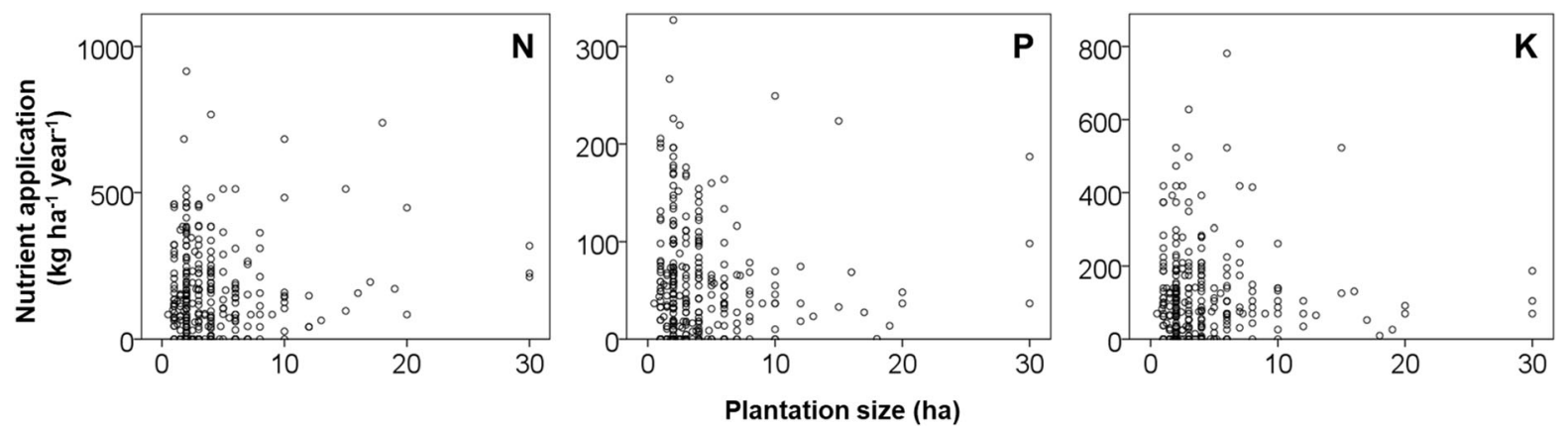

Fig. 5 Nutrient application as a function of plantation size. No significant correlation was observed

Fig. 6 Knowledge sharing networks in the research areas (a) and the topics that were discussed (b). The total counts add up to $>309$ because farmers could indicate multiple discussion partners and multiple topics of discussion

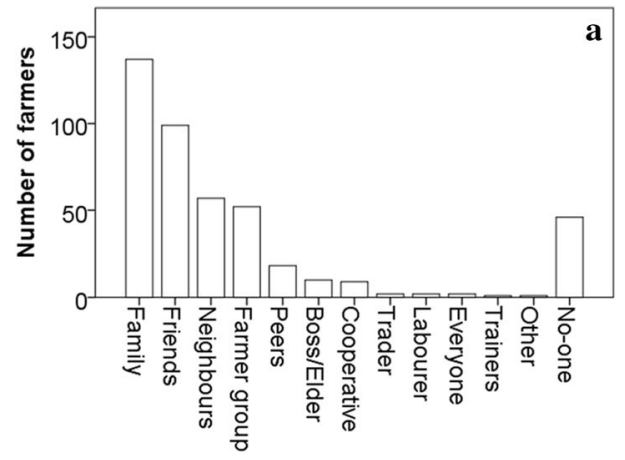

With whom do farmers share knowledge?

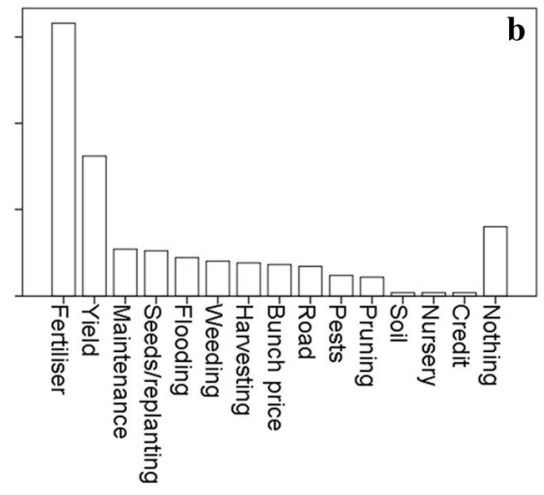

About what do farmers talk? our sample and in Indonesia. From both the literature and the survey it appeared that the K applications were the most limited in smallholder plantations compared with large plantations and with palm demand. While the average applications in our sample were well below the offtake rate at 20 tonne bunches $\mathrm{ha}^{-1}$ year $^{-1}$, the applications in Sintang were still larger than any of the $\mathrm{K}$ applications found in literature, and the $\mathrm{K}$ applications in the other areas were also large compared with most results from literature (Fig. 2). Although the $\mathrm{N}$ applications from the survey fell within the range observed in literature, they were larger than the average, with none falling below the average applications in Indonesia. Only for $\mathrm{P}$ were the applications estimated from the survey similar to the applications described in literature. There may be several reasons why the survey results for $\mathrm{N}$ and $\mathrm{K}$ were higher than those reported in literature. First, and most obviously, the training in the research area may have influenced farmers' decisions concerning fertiliser applications. When questioned about selfreported changes in fertiliser applications in recent years, more trained than untrained farmers indicated that they changed their practices in all of the research areas (data not shown), and a Wilcoxon signed rank test showed that this difference was statistically significant $(\mathrm{Z}=-2.023, p<0.05)$. However, no significant differences were observed between trained and untrained farmers with regards to $\mathrm{N}, \mathrm{P}$ and $\mathrm{K}$ applications in any of the research areas, which suggests that the reported changes in practice did not result in increased applications of $\mathrm{N}, \mathrm{P}$ and $\mathrm{K}$. In conclusion, the training effect on nutrient application does not adequately explain the higher $\mathrm{N}$ and $\mathrm{K}$ applications reported in our survey.

As an alternative explanation, our sample may have been biased towards better-performing farmers. This selection bias has been well documented (e.g. Feder et al. 2004) but may go both ways (Larsen and Lilleør 2014). It is likely that the choice of project areas was biased towards those that were relatively accessible and populated with farmers who were somewhat organised and willing to participate. Our data suggest that the choice of project participants was also biased 
toward farmers with larger farms, but no effect on nutrient application was observed. This indicates that constraints or enablers such as road quality, access to mills and markets, and farmer organisation may have a stronger effect on fertiliser use than plantation size and agronomic knowledge (Molenaar et al. 2010).

A fairly consistent picture of fertiliser use by smallholder farmers emerges from the results of our survey and from literature across different oil palm growing areas of Indonesia. Most farmers applied substantial amounts of fertilisers in their fields, especially $\mathrm{N}$ and $\mathrm{K}$. The differences among farmers and research areas were large, with some farmers applying no fertiliser whatsoever, and others applying excessive amounts, especially of N. Soliman et al. (2016) concluded that smallholder farmers "on average, could reduce their [...] fertiliser use by $65 \%$ and maintain the same yield". Our results show that this conclusion is not tenable, as it is based only on the rates of $\mathrm{N}$ applied. If farmers reduced their overall fertiliser use by $65 \%$, the additional shortages of $\mathrm{K}$ would probably lead to large reductions in yield. Rather than promoting an overall reduction in fertiliser use, we would suggest that the application of nutrients in the right balance deserves further attention. Palm age and soil type have a particularly strong influence on the nutrient needs of the palms. In most soils, the K requirement exceeds the $\mathrm{N}$ requirement (Foster 2003; Tohiruddin et al. 2006). Excessive $\mathrm{N}$ application may exacerbate K deficiency (Broschat 2009) and reduce yields. The case of phosphorus is complicated, as a large share of the $\mathrm{P}$ applied is usually fixed in the soil and will not be available to the palm (Foster and Prabowo 2006). Although the total palm demand for $P$ may be small, the application of substantial amounts of $\mathrm{P}$ fertiliser (1-2 $\mathrm{kg}$ rock phosphate per palm per year) is usually recommended to achieve good yields (Goh 2005). Large oil palm plantations make use of tissue sampling combined with randomised fertiliser trials to determine the optimum nutrient application in the plantation (Goh 2005). If tissue sampling is not feasible in smallholder plantations, then fertiliser recommendations need to be based on existing information about soil type and fertiliser requirements; visual deficiency symptoms; and suggestions from nearby plantations (Webb et al. 2011). A properlyevaluated basic fertiliser recommendation scheme for the most common soil types would be of great benefit to the smallholder farmers.
Most farmers in the sample heavily relied on subsidised fertilisers, especially urea and NPK Ponska. In order to access official supplies of subsidised fertilisers, farmers must be member of a farmer group and apply for the fertilisers collectively (Daemeter Consulting 2013). In practice, a large share of the fertilisers ends up on the market, where they are sold at an inflated price (Daemeter Consulting 2013). The large price difference between subsidised fertilisers and other fertilisers (particularly $\mathrm{KCl}$ ) is probably one of the main reasons why farmers tend to over-apply $\mathrm{N}$ and under-apply K (Molenaar et al. 2013). The economic rationale of investing in non-subsidised $\mathrm{K}$ fertilisers require further investigation, especially when returns on investment are constrained by low crude palm oil (CPO) prices and insecure relationships with mills, or responses to fertilisers are limited because of poor harvest quality, poor planting material, sub-optimal growing conditions (Cock et al. 2016) and increased climatic risks due to climate change (Paterson et al. 2017). Fake fertilisers are an additional risk, with fertilisers being replaced with cheaper materials, such as ground bricks in case of MOP (Daemeter Consulting 2013). In a small set of 10 fertiliser samples collected randomly in Sintang, Riau and Jambi, we found three fake fertilisers which contained little or no nutrients (data not shown). When farmers work together as a group, they may decide to test the fertilisers they purchase, but for individual farmers this is neither feasible nor affordable. We noted that many farmers were unaware of simple tests such as dissolving fertilisers in water. In addition to fake fertilisers, we found some very dubious products claiming fertiliser properties, such as bacterial and hormonal solutions. At least 10 farmers reported to use these products. One product sold as 'hormonal fertiliser' in Jambi provides a good illustration: it contains four different plant hormones, and according to the instructions it needs to be injected into the palm trunk every 3 months at a volume of $2 \mathrm{ml}$ per palm, dissolved in $10 \mathrm{ml}$ water. With a price of $120,000 \mathrm{Rp}$ per liter, the expenditure per hectare per year is over 80 USD for the input only, without considering the additional labour costs. It is worrying to see farmers invest in these types of products, but to restrict their use of mineral fertilisers such as MOP because they are considered too expensive.

Fertiliser application practices can be optimised to increase nutrient capture and use. From multiple field 
observations, we concluded that farmers usually applied all fertilisers in a narrow band around the palms. Most fertilisers were applied only once per year, rather than in multiple splits; and farmers often mixed fertilisers manually (data not shown). While available studies do not show any effect of fertiliser placement on oil palm yield (Goh et al. 2003, 2009), the even spreading of fertilisers on the largest possible soil area is considered sensible in mature plantations (Goh et al. 2003). In mature plantations the areas outside the circle are colonised by the palm roots (Foster and Tayeb 1986) and the application of fertilisers (particularly $\mathrm{P}, \mathrm{K}$ and $\mathrm{Mg}$ ) on top of decomposing fronds, rather than on the dry and bare soil in the palm circle close to the trunk has been recommended to improve fertiliser infiltration and reduce leaching and run-off (Maene et al. 1979; Foster and Tayeb 1986; Goh et al. 2003). The application of soluble fertilisers in at least two splits is common practice to reduce the risk of nutrient losses, especially on coarse soils (Goh et al. 2003). The manual mixing of straight fertilisers is obviously not recommended. Farmers use this as a labour-saving option, and are not aware of the poor fertiliser distribution that may result.

The efficiency of nutrient use depends among others on plantation maintenance, especially weeding. In total, over $44 \%$ of the farmers in the research sites indicated that they clear-weeded their plantations, usually by the application of paraquat $(>60 \%)$ or glyphosate $(35 \%)$. Clear-weeding leads to high vulnerability to soil erosion and fertiliser run-off, especially P. Improved weeding practices (i.e. the establishment of weeded circles and harvesting paths and the maintenance of a dense ground cover vegetation outside these areas; Rankine and Fairhurst 1999) can probably improve nutrient retention and infiltration. To catch nutrients, fronds may be stacked in boxes or lines along the contour. Most farmers $(75 \%)$ stacked dead fronds in a row, and $22 \%$ stacked the fronds in a box shape around the palms (data not shown). Frond stacking in boxes or along the contour line does not require additional inputs of materials and labour and can contribute to improved soil quality and increased nutrient use efficiency. It must be kept in mind that harvesters cut most of the fronds, but are paid per ton of harvested bunches. Monetary incentives could be a useful tool to improve stacking practices.
The return of empty fruit bunches (EFB) or EFBbased compost to farmers' fields is one of the most promising options to improve both palm nutrition and soil quality and fertility, without requiring large additional investments in fertilisers and without potential negative environmental impacts of excessive chemical fertiliser use (Chiew and Shimada 2013; Bessou et al. 2017). Empty bunches are a waste product of the milling process, and every five tonnes of FFB produce around one tonne of EFB. The positive effects of EFB applications on soil quality are well documented, and include strong increases in organic matter content, water holding capacity and water infiltration, and nutrient content (Chan et al. 1993; Comte et al. 2013). Empty bunches can be applied in several ways: directly as a mulch; incinerated to produce bunch ash; or mixed with palm oil mill effluent (POME) and composted for 2-4 months. The EFB are very rich in $\mathrm{K}$ (Donough et al. 2016), and an application of 25-40 ton ha ${ }^{-1}$ as mulch can meet the $\mathrm{K}$ demand of a high-yielding plantation for 1 year. Nutrients applied as organic fertiliser are less likely to leach into stream water than nutrients applied as mineral fertilisers (Comte et al. 2015). In peat soils, bunch ash can provide large quantities of $\mathrm{K}$ and alleviate soil acidity. Despite these benefits, EFB are often not available to, or used by, smallholder farmers (Molenaar et al. 2010), for several reasons. We observed that smallholder farmers often were unaware of the benefits of applying EFB, or they were afraid of pest problems. Farmers may also be discouraged by high transport and labour costs involved with spreading the EFB in the plantation, although anecdotal evidence from Jambi and Sintang suggested that the costs per kilo of $\mathrm{K}$ from EFB were generally smaller than from mineral fertiliser, even when including transport and labour costs. We also encountered anecdotal evidence of EFB loads going to waste at the mill, either because of poor distribution infrastructure or due to lack of demand (cf. Maitah et al. 2016). On the other hand, the availability of EFB for smallholder farmers may be an issue when stocks are bought up by plantation companies. To increase the EFB use by smallholder farmers, awareness building through training and demonstrations should be combined with ensuring farmer access to EFB at the mill. If plantation companies are allowed to buy up empty bunches at the expense of smallholder farmers, then there is a de facto stream of nutrients (especially $\mathrm{K}$ ) 
from resource-constrained smallholder plantations to company plantations. Leading trading and plantation companies (especially RSPO members) should commit themselves to ensuring that their mills implement fair and proper distribution of EFB to smallholder farmers.

\section{Conclusions}

Our study shows that smallholder farmers in Indonesia use much more fertiliser than is often assumed-but often of the wrong types. Increased applications of $\mathrm{K}$ fertiliser, combined with sufficient (but not excessive) applications of $\mathrm{N}$ and $\mathrm{P}$, are required to meet the palm nutrient demand. Subsidised fertilisers do not provide the correct nutrient balance, and therefore it is essential that farmers either use suitable blends or supplement with straight fertilisers, especially $\mathrm{K}$. Providing training on good agricultural practices to farmers does not appear to be sufficient to improve fertiliser application practices. In order to support good management of plant nutrition, farmers need to be connected with a reliable fertiliser dealer, purchase fertilisers collectively as a farmer group, or be provided with good-quality fertilisers by the mill they deliver to. For timely purchase of suitable fertilisers, farmers need access to credit through banks, cooperatives, or traders. The use of mobile devices and apps can help farmers to implement proper yield recording, which is necessary to support decision-making with regards to fertiliser applications. Regular application of empty fruit bunches in the plantation is important, in addition to correct application of mineral fertilisers. The implementation of low-cost practices such as proper management of the ground cover vegetation and stacking of the pruned fronds are beneficial for preventing soil erosion and improving soil quality. Good trainings and extension materials (such as posters and movies) dealing with the basics of soil science, plant physiology and plant nutrition should be made available for those farmers who are interested in becoming more knowledgeable. Supporting farmers to implement a more balanced approach to management of the mineral nutrition of oil palm offers the benefits of increased production, less risk of negative environmental impacts and higher profits.
Acknowledgements We thank all the participating farmers for their patience, openness, and hospitality. We thank Setara Jambi, Elang, WWF Indonesia, Keling Kumang Group, Good Return, Solidaridad, and SNV Indonesia for their support and willingness to share information and to allow for discussions with the participants in their projects. We thank Carien Meppelink, Kiki Zondag and Esther Jacobs for assisting in the data collection. Finally we thank IDH and Johnson \& Johnson Consumer Companies Inc. for their financial support.

Open Access This article is distributed under the terms of the Creative Commons Attribution 4.0 International License (http:// creativecommons.org/licenses/by/4.0/), which permits unrestricted use, distribution, and reproduction in any medium, provided you give appropriate credit to the original author(s) and the source, provide a link to the Creative Commons license, and indicate if changes were made.

\section{References}

Abood SA, Lee JSH, Burivalova Z, Garcia-Ulloa J, Koh LP (2015) Relative contributions of the logging, fiber, oil palm, and mining industries to forest loss in Indonesia. Conserv Lett 8(1):58-67

Afriyanti D, Kroeze C, Saad A (2016) Indonesia palm oil production without deforestation and peat conversion by 2050 . Sci Total Environ 557:562-570

Banabas M, Scotter DR, Turner MA (2008) Losses of nitrogen fertiliser under oil palm in Papua New Guinea: 2. Nitrogen transformations and leaching, and a residence time model. Aust J Soil Res 46(4):340-347

Bessou C, Verwilghen A, Beaudoin-Ollivier L, Marichal R, Ollivier J, Baron V, Bonneau X, Carron M-P, Snoeck D, Naim M (2017) Agroecological practices in oil palm plantations: examples from the field. Oilseeds Fats Crops Lipids. https://doi.org/10.1051/oc1/2017024

Broschat TK (2009) Palm nutrition and fertilization. HortTechnology 19(4):690-694

Chan KW, Lim KC, Ahmad A (1993) Fertilizer efficiency studies in oil palm. In: Basiron Y, Sukaimi J, Chang KC et al (eds) PIPOC 1991. Proceedings of the PORIM international palm oil conference: progress, prospects \& challenges towards the 21 st century, module 1: agriculture; 9-14 September; Kuala Lumpur. PORIM, Kuala Lumpur, pp 302-311

Chiew LK, Rahman ZA (2002) The effects of oil palm empty fruit bunches on oil palm nutrition and yield, and soil chemical properties. J Oil Palm Res 2:1-9

Chiew YL, Shimada S (2013) Current state and environmental impact assessment for utilizing oil palm empty fruit bunches for fuel, fiber and fertilizer-A case study of Malaysia. Biomass Bioenerg 51:109-124

Cock J, Kam SP, Cook S, Donough C, Lim YL, Jines-Leon A, Lim CH, Primananda S, Yen BT, Mohanaraj SN, Samosir YMS, Oberthür T (2016) Learning from commercial crop performance: oil palm yield response to management under well-defined growing conditions. Agric Syst 149:99-111 
Comte I, Colin F, Grunberger O, Follain S, Whalen JK, Caliman JP (2013) Landscape-scale assessment of soil response to long-term organic and mineral fertilizer application in an industrial oil palm plantation, Indonesia. Agric Ecosyst Environ 169:58-68

Comte I, Colin F, Grunberger O, Whalen JK, Widodo RH, Caliman JP (2015) Watershed-scale assessment of oil palm cultivation impact on water quality and nutrient fluxes: a case study in Sumatra (Indonesia). Environ Sci Pollut Res 22(10):7676-7695

Corley RHV (2009a) How much palm oil do we need? Environ Sci Policy 12(2):134-139

Corley RHV (2009b) Where do all the nutrients go? Planter 85(996): 133-147

Daemeter Consulting (2013) Fertilizer and oil palm in Indonesia. An overview of the industry and challenges for smallscale oil palm farmer applications. Daemeter Consulting, Bogor

Donough CR, Cahyo A, Wandri R, Fisher M, Oberthür T (2016) Plant nutrients in palm oil. Better Crops Plant Food 100(2):19-22

Euler M, Hoffmann MP, Fathoni Z, Schwarze S (2016) Exploring yield gaps in smallholder oil palm production systems in eastern Sumatra, Indonesia. Agric Syst 146:111-119

Euler M, Krishna V, Schwarze S, Siregar H, Qaim M (2017) Oil palm adoption, household welfare, and nutrition among smallholder farmers in Indonesia. World Dev 93:219-235

Feder G, Murgai R, Quizon JB (2004) Sending farmers back to school: the impact of farmer field schools in Indonesia. Rev Agric Econ 26(1):45-62

Foster HL (2003) Assessment of oil palm fertilizer requirements. In: Fairhurst T, Härdter R (eds) Oil palm: management for large and sustainable yields. Potash \& Phosphate Institute of Canada, Potash \& Phosphate Institute, International Potash Institute, Singapore, pp 231-257

Foster HL, Prabowo NE (2006) Partition and transfer of nutrients in the reserve tissues and leaves of oil palm. In: Proceedings of the workshop on nutrient needs in oil palm; 17-18 October; Singapore. PPI/PPIC and IPI, Singapore

Foster HL, Tayeb DMT (1986) The effect of different methods of placement and frequency of application of fertiliser to oil palm on an inland soil in Peninsula Malaysia. PORIM Bull 12:1-11

Gatto M, Wollni M, Qaim M (2015) Oil palm boom and landuse dynamics in Indonesia: the role of policies and socioeconomic factors. Land Use Policy 46:292-303

Gaveau DLA, Sheil D, Husnayaen Salim MA, Arjasakusuma S, Ancrenaz M, Pacheco P, Meijaard E (2016) Rapid conversions and avoided deforestation: examining four decades of industrial plantation expansion in Borneo. Sci Rep 6:32017

Goh KJ (2005) Fertilizer recommendation systems for oil palm: estimating the fertilizer rates. In: Soon CP, Pau TY (eds) Proceedings of the MOSTA best practices workshops on agronomy and crop management; 27 March-14 August 2004; Malaysia. MOSTA, Malaysia, pp 235-268

Goh KJ, Härdter R, Fairhurst T (2003) Fertilizing for maximum return. In: Fairhurst T, Härdter R (eds) The oil palmmanagement for large and sustainable yields. Potash \&
Phosphate Institute of Canada, Potash \& Phosphate Institute, International Potash Institute, Singapore, pp 279-306

Goh KJ, Ng PHC, Lee CT (2009) Fertiliser management and productivity of oil palm in Malaysia. In: Pushparajah E (ed) Proceedings of the 6th international planter conference on plantation agriculture and environment; 22-23 June 2009; Kuala Lumpur. Incorporated Society of Planters, Kuala Lumpur

Goodman LA (1961) Snowball sampling. Ann Math Stat 32(1):148-170

Gurmit Singh, Manoharan S, Toh TS (1990) United Plantations' approach to palm oil by-product management and utilization. In: Sukaimi J, Zakaria ZZ, Paranjothy K et al (eds) Proceedings of the international palm oil development conference, module ii: agriculture; 5-9 September 1989, Kuala Lumpur. PORIM, Kuala Lumpur, pp 225-234

Harsono SS, Prochnow A, Grundmann P, Hansen A, Hallmann C (2012) Energy balances and greenhouse gas emissions of palm oil biodiesel in Indonesia. GCB Bioenergy 4(2):213-228

Heffer P (2013) Assessment of fertilizer use by crop at the global level 2010-2010/11. International Fertilizer Industry Association, Paris

Janssen BH, Guiking FCT, Vandereijk D, Smaling EMA, Wolf J, Vanreuler H (1990) A system for quantitative evaluation of the fertility of tropical soils (QUEFTS). Geoderma 46(4):299-318

Koczberski G, Curry GN (2003) Sustaining production and livelihoods among oil palm smallholders: a socio-economic study of the Bialla smallholder sector. Curtin University of Technology, Perth

Larsen AF, Lilleør HB (2014) Beyond the field: the impact of farmer field schools on food security and poverty alleviation. World Dev 64:843-859

Lee JSH, Ghazoul J, Obidzinski K, Koh LP (2013) Oil palm smallholder yields and incomes constrained by harvesting practices and type of smallholder management in Indonesia. Agron Sust Dev 34(2):501-513

Lifianthi, Husin L (2012) Productivity and income performance comparison of smallholder oil palm plantation at dry land and wet land of South Sumatra Indonesia. APCBEE Procedia 3:270-275

Maene LM, Thong KC, Ong TS, Mokhtaruddin AM, Pushparajah E (1979) Surface wash under mature oil palm. In: Pushparajah E (ed) Proceedings of the 1979 symposium on water in Malaysian agriculture; 16-17 March; Kuala Lumpur. Malaysian Society of Soil Science, Kuala Lumpur, pp 203-216

Maitah M, Prochazka P, Pachmann A, Sredl K, Rezbova H (2016) Economics of palm oil empty fruit bunches bio briquettes in Indonesia. Int J Energy Econ Pol 6(1):35-38

Molenaar JW, Orth M, Lord S, Meekers P, Taylor C, Darto M, Elson D, Ginting L (2010) Analysis of the agronomic and institutional constraints to smallholder yield improvement in Indonesia. AidEnvironment, Amsterdam

Molenaar JW, Persch-Ort M, Lord S, Taylor C, Harms J (2013) Diagnostic study on Indonesian oil palm smallholders: developing a better understanding of their performance and potential. International Finance Corporation, Jakarta 
Murdiyarso D, Hergoualc'h K, Verchot LV (2010) Opportunities for reducing greenhouse gas emissions in tropical peatlands. PNAS 107(46):19655-19660

Ng HCP, Chew PS, Goh KJ, Kee KK (1999) Nutrient requirements and sustainability in mature oil palms-an assessment. Planter 75(880):331-345

Papenfus MM (2002) Investing in oil palm: an analysis of independent smallholder oil palm adoption in Sumatra, Indonesia. Southeast Asia policy research working paper no. 15. ICRAF Southeast Asia, Bogor

Paterson RRM, Kumar L, Shabani F, Lima N (2017) World climate suitability projections to 2050 and 2100 for growing oil palm. J Agric Sci 155(5):689-702

Rankine IR, Fairhurst TH (1999) Field handbook: oil palm series, volume 3-mature, 2nd edn. Potash \& Phosphate Institute (PPI), Singapore

Rietberg P, Slingerland M (2016) Costs and benefits of RSPO certification for independent smallholders. A science-forpolicy paper for the RSPO. Wageningen University, Wageningen

Rival A, Montet D, Pioch D (2016) Certification, labelling and traceability of palm oil: can we build confidence from trustworthy standards? Oilseeds Fats Crops Lipids 23(6):D609

RSPO (2013) Principles and criteria for the production of sustainable palm oil. Roundtable on Sustainable Palm Oil, Kuala Lumpur

RSPO (2017) RSPO Smallholders Support Fund (RSSF). Roundtable on Sustainable Palm Oil, Kuala Lumpur. http:// www.rspo.org/smallholders/rspo-smallholders-supportfund. Accessed 24 May 2017
Smit HH, Meijaard E, van der Laan C, Mantel S, Budiman A, Verweij P (2013) Breaking the link between environmental degradation and oil palm expansion: a method for enabling sustainable oil palm expansion. PLoS ONE 8(9):e68610

Soliman T, Lim FKS, Lee JSH, Carrasco LR (2016) Closing oil palm yield gaps among Indonesian smallholders through industry schemes, pruning, weeding and improved seeds. R Soc Open Sci 3(8): 160292

Tohiruddin L, Prabowo NE, Foster HL (2006) Comparison of the response of oil palm to fertilisers at different locations in North and South Sumatra. Paper presented at: IOPC 2006. Proceedings of the international oil palm conference; 19-23 June; Nusa Dua, Bali

USDA (2017) Indonesia oilseeds and products annual report 2017. USDA Foreign Agricultural Services, Jakarta

Van Noordwijk M, Cadisch G (2002) Access and excess problems in plant nutrition. Plant Soil 247(1):25-40

Vermeulen S, Goad N (2006) Towards better practice in smallholder palm oil production. International Institute for Environment and Development, London

Webb MJ (2009) A conceptual framework for determining economically optimal fertiliser use in oil palm plantations with factorial fertiliser trials. Nutr Cycl Agroecosys 83(2): $163-178$

Webb MJ, Nelson PN, Rogers LG, Curry GN (2011) Sitespecific fertilizer recommendations for oil palm smallholders using information from large plantations. J Plant Nut Soil Sci 174(2):311-320 